\title{
Combination of immunoprecipitation (IP)-ATP_Glo kinase assay and melanogenesis for the assessment of potent and safe PAK1- blockers in cell culture
}

\author{
Binh Cao Quan Nguyen ${ }^{1,2, *}$, Pham Thi Be Tu, ${ }^{1,2,}$, Shinkichi Tawata ${ }^{1}$, Hiroshi Maruta,** \\ ${ }^{1}$ PAK Research Center, Okinawa, Japan; \\ ${ }^{2}$ Department of Biochemistry and Applied Bioscience, The United Graduate School of Agricultural Sciences, Kagoshima \\ University, Kagoshima, Japan.
}

\begin{abstract}
Summary Cucurbitacin I (CBI) is a triterpene from a bitter melon called Goya grown in Okinawa, Japan, and directly inhibits both the Tyr-kinase JAK2 and the G protein RAC, leading to the inactivation of PAK1 (RAC/CDC42-activated kinase 1). Bio 30, a propolis produced in New Zealand, contains CAPE (caffeic acid phenethyl ester) as the major anti-cancer ingredient which directly down-regulates RAC, leading to the inactivation of PAK1. Since PAK1 is essential for the growth of RAS cancer cells such as A549 cell line which carry an oncogenic K-RAS mutant, and the melanogenesis in skin cells, here using these PAK1blockers as model compounds, we introduce a new approach to the quick assessment of PAK1-blockers in cell culture. First, combining the immuno-precipitation (IP) of PAK1 from cell lysate and the in vitro ATP Glo kinase assay kit (called "Macaroni-Western" assay), we confirmed that both CBI and Bio 30 inactivate PAK1 in A549 lung cancer cells in $24 \mathrm{~h}$, and inhibit their PAK1-dependent growth in $\mathbf{7 2} \mathrm{h}$. Furthermore, we verified that CBI inhibits the PAK1/PAK4-dependent melanogenesis in melanoma cells by far more than $50 \%$, while Bio 30 inhibits the melanogenesis only by $50 \%$, with only a merginal effect on their growth per se. Since the "Macaroni-Western" kinase assay and melanogenesis are both rather simple and quick, the combination of these two cell culture assays would be highly useful for selecting both "potent" (highly cell-permeable) and "safe" (non-toxic) natural or synthetic PAK1-blockers.
\end{abstract}

Keywords: PAK1, melanogenesis, immunoprecipitation, ATP_Glo kinase assay, cucurbitacin, propolis

\section{Introduction}

PAK1 (RAC/CDC42-activated kinase 1) is essential for the growth of various solid tumors and a numerous other diseases such as AD (Alzheimer's disease), PD (Parkinson's disease), epilepsy, schizophrenia, depression, autism, diabetes (type 2), hypertension, obesity, inflammatory diseases, and infectious diseases (1). Also it has recently shown to be essential for the melanogenesis in skin cells (2). Thus, PAK1-

\footnotetext{
*These authors contributed equally to this work.

**Address correspondence to:

Dr. Hiroshi Maruta, PAK Research Center, 1-Senbaru,

Nishihara-cho, Okinawa 903-0213, Japan.

E-mail: maruta20420@yahoo.co.jp
}

blockers would have a potentially huge market value as therapeutics and cosmetics. However, so far only a few PAK1-blockers are available on the market. Thus, a quick, inexpensive and simple screening system is needed for identification and development of potent (highly cell permeable) and safe (non-toxic) PAK1blockers.

In the past decade(s), the initial screening for PAK1-blockers has been performed mainly in test tubes to select compounds that inhibit directly PAK1. Unfortunately, however, most of these PAK1-inhibitors turned out to have a poor cell-permeability. For instance, the $\mathrm{IC}_{50}$ for PAK1 in test tube of FRAX486 and FRAX597 are around $10 \mathrm{nM}$, but their $\mathrm{IC}_{50}$ for the PAK1-dependent growth of NF2-deficient tumor cells in cell culture are above $1 \mu \mathrm{M}(1000 \mathrm{nM})$. Since the 
NF2 gene product (merlin) is a PAK1 inhibitor (1), it is most likely that less than 100th of these molecules could pass through cell membranes $(3,4)$. In order to screen for highly cell-permeable PAK1-blockers more effectively, we have to conduct the assessment of test compounds in cell culture or in vivo, instead of in test tubes, in the earliest possible stage, in order to save both time and money. The current peculiar culture among pharmaceuticals that puts the first priority on the kinasespecificity of each compound in test tube over its cellpermeability needs to be reconsidered, simply because no drug would be useful for clinical application, if it hardly passes through the cell membranes.

Here we present a new approach to the more effective assessment of PAK1-blockers in cell culture, based on the fact that PAK1 and PAK4 independently contribute to melanogenesis (each by around 50\%) (2). In addition, instead of the rather unreliable pPAK1-blot analysis, combining the IP (immuno-precipitation) of PAK1 from cells treated with a given compound, and in vitro ATP_Glo kinase assay kit (5), we introduced the "Macaroni-Western" PAK1 assay system to determine whether a given compound inactivates PAK1 in cell culture or not. Here we used two potent herbal PAK1blockers called cucurbitacin I (CBI) and Bio 30, a CAPE (caffeic acid phenethyl ester)-based propolis as model test samples. In the past, it was shown that cucurbitacin D (CBD) which is structurally related to CBI, inhibits the melanogenesis in melanoma cells almost completely (6), while CAPE from a propolis inhibits the melanogenesis only by $50 \%$ (7). In the light of our recent findings, it is speculated that CBD blocks both PAK1 and PAK4, while CAPE blocks only PAK1.

In the past, basically two ways were used to assay the kinase activity of PAK1 in cell culture. The first (old) assay method is a "radioactive" approach in which PAK1 is immunoprecipitated (IP) with a polyclonal antibody (IgG) against PAK1 from cell lysates by means of protein A/G beads, and the resulting PAK1-IgGbead complex is then incubated with the "radioactive" (gamma- ${ }^{32} \mathrm{P}$ ) ATP and the substrate MBP (myelin basic protein) in vitro (test tube), and the phosphorylated (radioactive) MBP band is separated by SDS-PAGE, and the radioactivity of this band is quantitated by the auto-radiography (8). This method is getting less and less popular in this century, simply because the handling of radioisotopes is rather restricted in research laboratories world-wide.

The alternative (more recent) approach is the immuno-blot (also called "western-blot") approach in which a cell-lysate is separated by SDS-PAGE, and proteins including PAK1 are transferred onto nitrocellulose paper, and phosphorylated PAK1 (called "pPAK1" at Thr423, Ser199, or Ser144, case by case) band is blotted with an antibody against each pPAK1, and in the end the amount of this antibody is quantified by fluorescence technique associated with probes (biotin or horse radish labeling). Unfortunately, however, the "western-blot" analysis based on pPAK1 is not reliable, simply because the activation of PAK1 in cells does not always depend on the auto-phosphorylation of PAK1 at these Ser/Thr residues. The full activation of PAK1 depends on its Tyr-phosphorylation by three distinct Tyr-kinases (ETK, JAK2 and FYN) at least (9-11), and dephosphorylation of PAK1 at $\mathrm{Thr}^{109}$ as well (12). For instance, melanogenic hormones such as $\alpha$-melanocytestimulating hormone ( $\alpha$-MSH) and 3-isobutyl-1-methyl xanthine (IBMX) activate PAK1 in melanoma cells, with no change in pPAK1 (Thr423) level (2). Thus, strictly speaking, this popularized and over-simplified pPAK1-based "western-blot" analysis is rather unreliable or misleading, least to speak.

Around a decade ago, an Italian group introduced a third kinase assay system which we call here "MacaroniWestern" kinase assay (5). This is a clever modification of the old radioactive approach by simply replacing "radioactive" ATP with a newly developed "ATP Glo kinase assay kit" (Promega). Accordingly, PAK 1 immunoprecipitated from cell lysates (after cells are treated with a given test compound) is incubated with this kit with ATP and MBP, and the remaining ATP could be quantified by the ATP-dependent "luciferin-luciferase" reaction which produces the fluorescence/luminescence. Thus, the universal "Macaroni-Western" system allows us to monitor any change in the kinase activity of PAK1 in cells directly, independent of its auto-phosphorylation sites, without SDS-PAGE.

\section{Materials and Methods}

\subsection{Reagents and cell lines}

Cucurbitacin I (CBI) was purified from bitter melon called "Goya" by our own laboratory as previously described (13). Bio 30, a CAPE (caffeic acid phenethyl ester)-based propolis (tincture) from New Zealand was obtained from Manuka Health in Auckland. The content of major ingredients in Bio 30 was described in detail previously (14).

Human A549 lung cancer cell line and murine B16F10 melanoma cell line were obtained from Japanese Collection of Research Bioresources Cell Bank (Osaka, Japan) and American Type Culture Collection (ATCC; Rockville, MD, USA), respectively. 3-(4,5-dimethylthiazol-2-yl)-2,5-diphenyl-tetrazolium bromide (MTT), myelin basic protein (MBP) and protein A-agarose beads were purchased from Sigma Aldrich Chemical Co. (St. Louis, MO, USA). Rabbit polyclonal anti-PAK1 IgG was obtained from Cell Signalling Technology (Danver, MA, USA). Kinase Glo reagent and ATP (ATP_Glo kinase kit) were purchased from Promega (Madison, Wisconsin, USA). Dulbecco's modified Eagle medium (DMEM), 3-isobutyl-1methyl xanthine (IBMX), fetal bovine serum (FBS), 
and triton-X were purchased from Wako Pure Chemical Industries, Ltd. (Osaka, Japan). All reagents were of the highest grade available.

\subsection{Cell culture}

Human A549 lung cancer cell line was cultured as described previously (13). Murine B16F10 melanoma cell line was cultured as described previously $(2,15)$.

\subsection{MTT assay for cell viability or growth of B16F10 and $A 549$ cell lines}

Cell viability (or growth rate) was determined using an MTT assay, as previously described (16). Briefly, B16F10 or A549 cells $\left(2 \times 10^{4}\right.$ cells/well) were seeded on a 24 -well plate. After $48 \mathrm{~h}$ of preculture, cells were treated with either CBI or Bio 30 at various concentrations for either $48 \mathrm{~h}(\mathrm{~B} 16 \mathrm{~F} 10)$ or $24 \mathrm{~h}$ and $72 \mathrm{~h}$ (A549) at $37^{\circ} \mathrm{C}$. Then cells were washed with phosphate buffer and incubated with MTT solution $(0.5 \mathrm{mg} / \mathrm{mL})$ for $3 \mathrm{hrs}$ at $37^{\circ} \mathrm{C}$. After the medium was replaced by $200 \mu \mathrm{L}$ of ethanol, the absorbance of each well was measured at $570 \mathrm{~nm}$ using a microplate spectrophotometer (Bio-Rad Laboratories, Inc., Hercules, CA, USA)

\subsection{Measurement of melanin content}

Melanin content was determined as previously described (17). In brief, B16F10 cells were plated at a density of $2 \times 10^{4}$ cells/well in a 24 -well plate. After $48 \mathrm{~h}$ of preculture, cells were treated with either CBI (100-800 $\mathrm{nM})$ or Bio 30 (1-16 $\mu \mathrm{g} / \mathrm{mL})$. After $1 \mathrm{~h}, 100 \mu \mathrm{M}$ isobutyl1-methylxanthine (IBMX), a melanogenic hormone which activates PAK1 (2), was added and incubated for additional $48 \mathrm{hrs}$ at $37^{\circ} \mathrm{C}$. After washed with phosphate buffer, cells were dissolved in $500 \mu \mathrm{L} \mathrm{NaOH}(1 \mathrm{~N})$ containing 10\% dimethyl sulfoxide (DMSO). Samples were incubated at $80^{\circ} \mathrm{C}$ for $1 \mathrm{~h}$, to solubilize the melanin. The optical density of the mixed homogenate was measured at $490 \mathrm{~nm}$.

\section{5. "Macaroni-Western" (IP-ATP_Glo) kinase assay for PAK1 in A549 cells}

\subsubsection{Protocol for drug-treatment of cells followed by IPing PAK1 from cell lysates}

The intracellular content of PAK1 is quite low compared with other kinases. Thus, in an attempt to optimize the selective immuno-precipitation (IP) of PAK1 alone, in particular for minimizing the non-specific binding of other kinases to beads, and maximizing the IgGprotein A beads interaction, the following protocol for monitoring the effect of test drugs on PAK1 activity in cell culture includes our substantial improvement of a decade old method (which we coined "Macaroni-
Western") published by an Italian group who initially developed for monitoring in test tube the direct effect of drugs on a variety of native abundant kinases such as CDKs (cyclin-dependent kinases) from cultured cells (5). The initial concentration of ATP for "test tube" kinase assay also has been optimized for monitoring both activation and inactivation of PAK1 in cells by a variety of test drugs.

Step 1: pre-culture A549 lung cancer cell line $\left(2 \times 10^{5}\right.$ cells $/ \mathrm{mL}$ ) on 6-well plate for $24 \mathrm{~h}$.

Step 2: replace by the fresh medium containing test compounds at various concentrations, and incubate for $24 \mathrm{~h}$.

Step 3: wash with $500 \mu \mathrm{L}$ of ice-cold PBS (-) twice.

Step 4: add $500 \mu \mathrm{L}$ of $50 \mathrm{mM}$ Tris- $\mathrm{HCl} \mathrm{pH} 7.5$ and $150 \mathrm{mM} \mathrm{NaCl}$ and $1 \%$ Triton-X (lysis buffer).

Step 5: incubate on ice for $30 \mathrm{~min}$.

Step 6: cell lysates were transferred into $1.5 \mathrm{~mL}$ tube.

Step 7: spin at 1,000 rpm for $5 \mathrm{~min}$ at $4^{\circ} \mathrm{C}$.

Step 8: transfer the supernatant to $1.5 \mathrm{~mL}$ new tubes.

Step 9: add $50 \mu \mathrm{L}$ of dilution buffer alone or antiPAK1 IgG (1:50 dilution)* to each tube.

Step 10: incubate for $1 \mathrm{~h}$ on ice.

Step 11: add $10 \mu \mathrm{L}$ of protein A-agarose beads.

Step 12: incubate for $1 \mathrm{~h}$ in cold room with continuous shaking by a rotary mixer (Nissin, Suginamiku, Tokyo, Japan).

Step 13: spin at $1,000 \mathrm{rpm}$ for $5 \mathrm{~min}, 4^{\circ} \mathrm{C}$.

Step 14: remove the supernatant.

Step 15: resuspend the pellet with $500 \mu \mathrm{L}$ of $50 \mathrm{mM}$ Tris- $\mathrm{HCl} \mathrm{pH} 7.5$ and $150 \mathrm{mM} \mathrm{NaCl}$ (washing buffer).

Step 16: spin at $1000 \mathrm{rpm}$ for $5 \mathrm{~min}, 4^{\circ} \mathrm{C}$.

Step 17: repeat steps 15 and 16.

Step 18: resuspend the PAK1 pellet in $35 \mu \mathrm{L}$ of 50 $\mathrm{mM}$ Tris- $\mathrm{HCl} \mathrm{pH} 7.5$ and $150 \mathrm{mM} \mathrm{NaCl}, 20 \mathrm{mM} \mathrm{MgCl}_{2}$, $0.1 \mathrm{mg} / \mathrm{mL}$ BSA (kinase buffer).

*Note: Anti-PAK1 IgG is diluted in buffer (50 mM Tris $\mathrm{pH} 7.5,150 \mathrm{mM} \mathrm{NaCl}, 100 \mu \mathrm{g} / \mathrm{mL}$ BSA) in ratio 1:50 (dilution buffer)

\subsubsection{ATP_ Glo kinase assay}

PAK1 assay was carried out in a $100 \mu \mathrm{L}$ total volume. $35 \mu \mathrm{L}$ of kinase buffer alone or immuno-precipitated PAK 1 and $5 \mu \mathrm{L}$ of the substrate MBP $(1 \mathrm{mg} / \mathrm{mL}$ in distilled water) were incubated at $37^{\circ} \mathrm{C}$ for $10 \mathrm{~min}$. Then, $10 \mu \mathrm{L}$ of $2 \mu \mathrm{M}$ ATP in distilled water was added to each well. The reaction was incubated for 1 hr at $37^{\circ} \mathrm{C}$ with continuous shaking. After the kinase reaction, the equal volume $(50 \mu \mathrm{L})$ of kinase Glo reagent (Promega) was added to each well, and the plate was further incubated for $30 \mathrm{~min}$ to stabilize luminescent signal. The suspension was centrifuged, and the supernatant was transferred to 96-well plate for reading. Luminescence was recorded by MTP-880Lab microplate reader (Corona, Hitachinaka-ku, Ibaraki, Japan) with an integration time of $0.5 \mathrm{~s}$ per well. 


\subsection{Effect of CBI and Bio 30 on the growth of A549} cancer cells

A549 cells were seeded on 6-well plate at the density of $2 \times 10^{5}$ cells/well in D-MEM supplemented with $10 \%$ FBS, and after preculture for $24 \mathrm{~h}$, cells were treated with either CBI or Bio 30 at indicated concentrations for further $72 \mathrm{~h}$. Then cells were stained with trypan blue as described previously (18). Both dead cells and the total cells were counted using hemocytometer. The percentage of viable treated cells in relative to the control (nontreated) cells was calculated.

\subsection{Statistical analysis}

Data are expressed as mean values with their standard errors. Statistical comparisons were performed by oneway ANOVA followed by Duncan's multiple-range test. Statistical analysis was conducted using SAS (release 9.2; SAS Institute, Cary, NC, USA) and $p<0.05$ was considered significant.

\section{Results and Discussion}

3.1. "Macaroni-Western" kinase assay for the inactivation of PAK1 by $C B I$ and Bio 30 in cell culture for $24 \mathrm{~h}$

In this study, we have chosen $\mathrm{CBI}$ and Bio 30 as potential model PAK1-blockers for the following reasons: CBI inhibits directly two activators (JAK2 and RAC) of PAK1 $(19,20)$, while Bio 30 contains CAPE which down-regulates RAC by inhibiting directly AKR (AldoKeto-Reductase) 1B10 (21), and suppresses completely the PAK1-dependent growth of NF2-deficient tumor (schwannoma) in vivo (14).

Since the PAK1 (protein) level in melanoma cell line B16F10 is extremely low (15), as the PAK 1 source for the "Macaroni-Western" kinase assay, we used A549 lung cancer cell line in which the oncogenic K-RAS mutant highly activates PAK1, and whose growth almost solely depends on PAK1. After preculture of A549 cells for $24 \mathrm{~h}$, they were treated with either CBI or Bio 30 at two indicated concentrations for $24 \mathrm{~h}$, and the non-treated cells as well as treated cells were lyzed, and cell lysates were incubated with anti-PAK1 IgG and protein A-beads for immuno-precipitation (IP) of PAK1. After the PAK1IgG-protein A-bead complex was incubated with ATP and MBP for $1 \mathrm{~h}$, ATP_Glo kinase assay kit was added to measure the remaining ATP level by the released luminescence (for detail, see Figure 1). The higher the luminescence, the lower the kinase activity. As shown in Figure 2, both CBI and Bio 30 clearly inactivate PAK 1 in this cancer cell line with the apparent $\mathrm{IC}_{50}$ around $600 \mathrm{nM}$ and $60 \mu \mathrm{g} / \mathrm{mL}$, respectively. The apparent down-regulation of PAK1 by these
"Macaroni-Western" ( IP-ATP_Glo) Kinase Assay

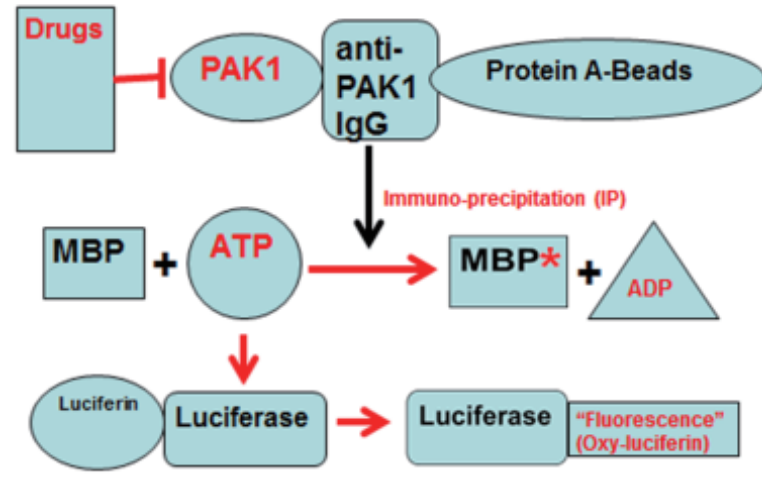

Figure 1. "Macaroni-Western" (IP-ATP_Glo) kinase assay. PAK1 is treated (activated or inactivated) with a given test sample in cell culture, and PAK1 is immunoprecipitated (IP) from cell lysate, and its kinase activity is measured by ATP_Glo kinase kit in test tube using ATPdependent luciferin/luciferase reaction.

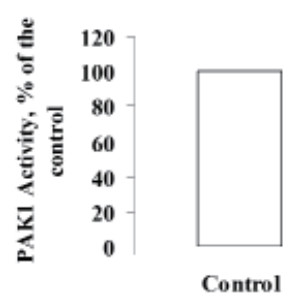

A)

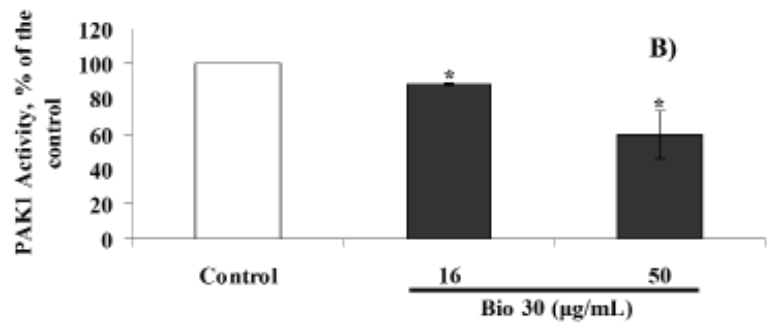

Figure 2. Both CBI (A) and Bio 30 (B) inactivate PAK1 in A549 cancer cells for $\mathbf{2 4} \mathbf{h}$. Inactivation of PAK1 in cells with $\mathrm{CBI}$ and Bio 30 was monitored by the "MacaroniWestern" kinase assay in test tube. For detail of the assay procedure, see under Materials and Methods. Data have significant difference by ANOVA analysis at $p \leq 0.05$. Statistically significant differences relative to control are indicated by asterisks. $* 0.01 \leq p \leq 0.05, * * p<0.01$.

compounds is not due to the growth inhibition of this cell line by these compounds, because for the first $24 \mathrm{~h}$ (just one generation of cell cycle) no growth inhibition was observed with either CBI or Bio 30 (see Figure 3).

\subsection{Growth inhibition of $A 549$ cancer cells by CBI and Bio 30 for $72 \mathrm{hrs}$}

However, after treatment of A549 cancer cells with either CBI or Bio 30 for $72 \mathrm{~h} \mathrm{(3-4} \mathrm{generations} \mathrm{of} \mathrm{cell}$ cycle), both CBI and Bio 30 strongly inhibit the growth of this "RAS" cancer cell line with the $\mathrm{IC}_{50}$ around 

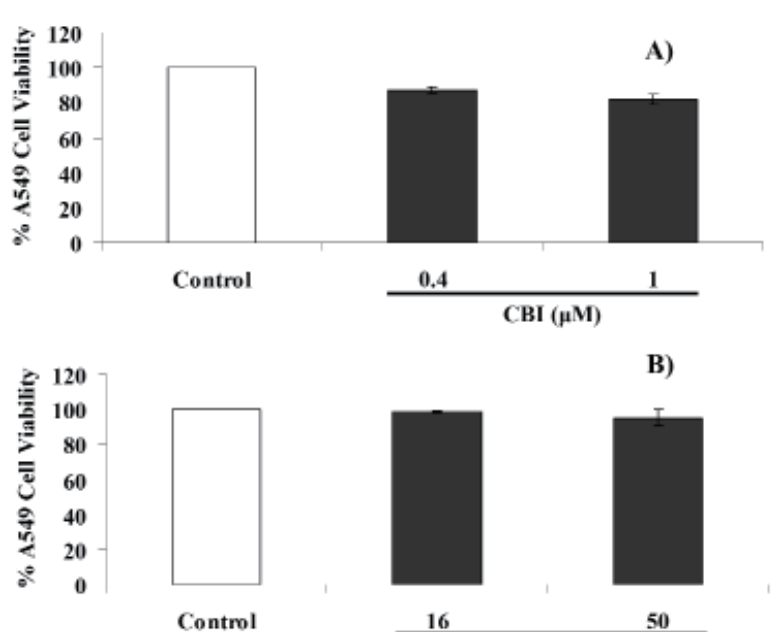

B)
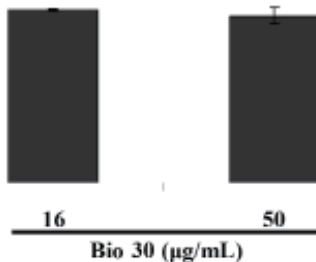

Figure 3. Neither CBI (A) nor Bio 30 (B) affects the viability/growth of A549 cells for the first $\mathbf{2 4} \mathrm{h}$. Data have significant difference by ANOVA analysis at $p \leq 0.05$.
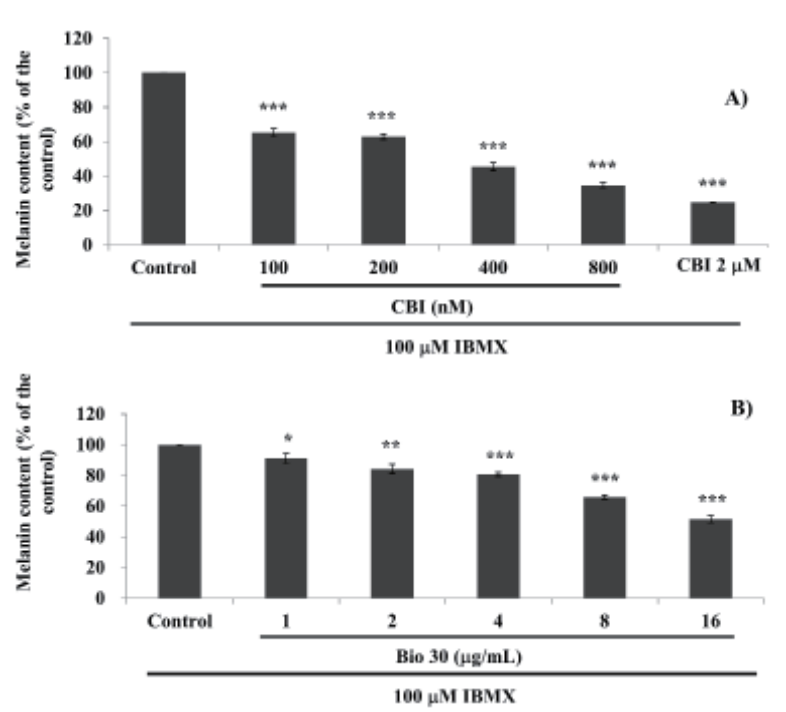

Figure 5. Both CBI (A) and Bio 30 (B) inhibit the melanogenesis in melanoma cells for $72 \mathbf{h}$. The $\mathrm{IC}_{50}$ of $\mathrm{CBI}$ and Bio 30 are around $400 \mathrm{nM}$ and $16 \mu \mathrm{g} / \mathrm{mL}(\mathrm{ppm})$, respectively. Data have significant difference by ANOVA analysis at $p \leq 0.05$. Statistically significant differences relative to control are indicated by asterisks. $* 0.01 \leq p \leq 0.05$, ** $p<0.01,{ }^{* * *} p<0.001$.

$140 \mathrm{nM}$ and $8 \mu \mathrm{g} / \mathrm{mL}$, respectively (see Figure 4), confirming that PAK1 is absolutely essential for the growth of this RAS cancer cell line.

The major and most likely reason why the $\mathrm{IC}_{50}$ for the growth is several times lower than the apparent $\mathrm{IC}_{50}$ for the kinase activity is the following: both IP procedure and test tube assay for PAK1 activity isolated from cells takes more than $3 \mathrm{hrs}$ in total, and in the absence of PAK1-blockers (CBI and Bio 30), the suppression of PAK1 activity could be gradually released over time. In other words, during
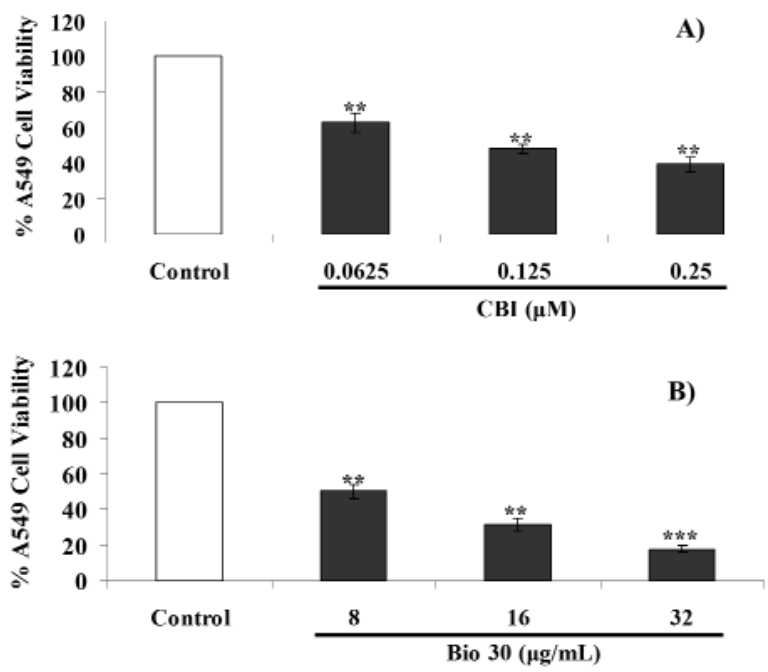

Figure 4. Both CBI (A) and Bio 30 (B) inhibit the growth of $\mathbf{A 5 4 9}$ cells for $\mathbf{7 2} \mathbf{h}$. The $\mathrm{IC}_{50}$ of CBI and Bio 30 are around $140 \mathrm{nM}$ and $8 \mu \mathrm{g} / \mathrm{mL}(\mathrm{ppm})$, respectively. Data have significant difference by ANOVA analysis at $p \leq 0.05$. Statistically significant differences relative to control are indicated by asterisks. ${ }^{* *} p<0.01,{ }^{* * *} p<0.001$.
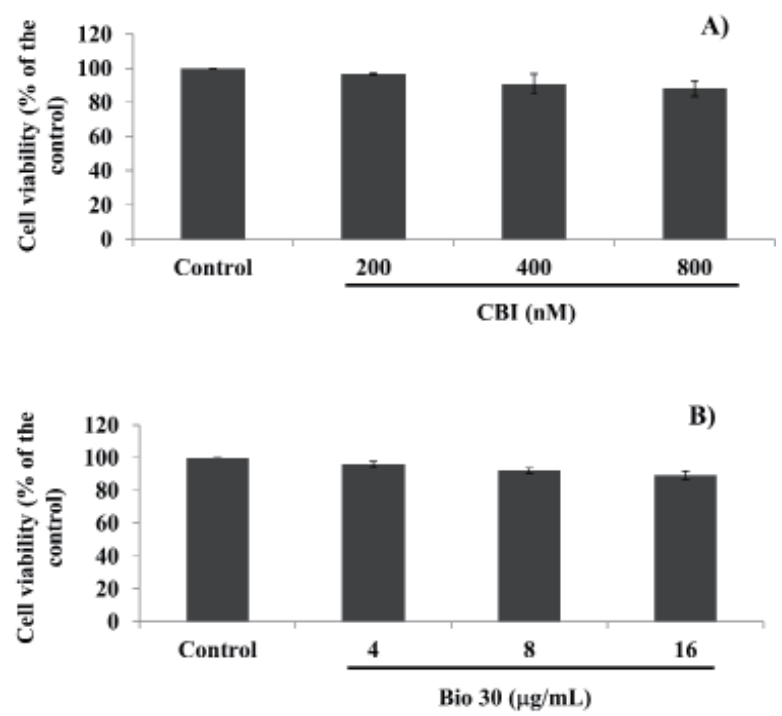

Figure 6. Either CBI (A) or Bio 30 (B) shows little effect on the viability/growth of melanoma cells during $48 \mathrm{~h}$. Data have significant difference by ANOVA analysis at $p \leq$ 0.05 .

this "time-consuming" test tube kinase assay, we cannot freeze the exact (activated or inactivated) status of PAK1 in the end of cell-treatment. That is the major demerit associated with this kinase assay, although any significant change in the kinase activity during cell culture can be monitored regardless of the phosphorylation sites of PAK1. Thus, the apparent $\mathrm{IC}_{50}$ for the kinase assay obtained in test tube is only a reflection of PAK1 inhibition during cell culture, and not the true $\mathrm{IC}_{50}$ during cell culture. Nevertheless, the apparent $\mathrm{IC}_{50}$ tells clearly that $\mathrm{CBI}$ is far more potent 
than Bio 30 in suppressing PAK1 during the cell culture, as does in the cancer cell growth.

\subsection{Anti-melanogenic effect of $C B I$ and Bio 30}

We and others recently established that both PAK1 and PAK4 are essential for the melanogenesis of skin cells such as melanoma cell line B16F10, and each contributes independently by around $50 \%$ to their melanogenesis $(2,15)$. In other words, if a given compound blocks only PAK 1 or PAK4, it could inhibit the melanogenesis only by $50 \%$ at the highest concentrations, whereas if a given compound blocks both kinases, it could inhibit the melanogenesis almost completely, as does the pan-PAK inhibitor PF3758309 at $300 \mathrm{nM}$ (15). As shown in Figure 5, CBI inhibits the melanogenesis by more than $70 \%$ at $800 \mathrm{nM}$, whereas Bio 30 inhibits the melanogenesis only by $50 \%$ at 16 $\mu \mathrm{g} / \mathrm{mL}$. Under these concentrations, either CBI or Bio 30 showed only a marginal effect on the growth of the melanoma cells (see Figure 6). In addition, we have confirmed that melanogenic stimulators such as IBMX and $\alpha$-MSH indeed activate significantly the kinase activity of PAK1 in this melanoma cell line as judged by the "Macaroni-Western kinase assay" (2). It might be worth noting that the $\mathrm{IC}_{25}$ of Bio 30 for the PAK1/ PAK4-dependent melanogenesis is around $8 \mu \mathrm{g} / \mathrm{mL}$, which is the same of the $\mathrm{IC}_{50}$ for the PAK1-dependent growth of A549 cells, suggesting that when Bio 30 inactivates PAK 1 by $50 \%$, both the PAK1-dependent cancer cell growth and melanogenesis are reduced to around a half.

These findings indicate the following two things: $(i)$ it is most likely that CBI blocks both PAK1 and PAK4 as CBD does, while Bio 30 probably blocks only PAK1 as CAPE does. (ii) the growth of A549 cancer cells depends on PAK1, while the growth of melanoma cell line B16F10 is independent of PAK1. In other words, either CBI or Bio 30 is not simply a poison, but both are highly selective (non-poisonous) and cell-permeable PAK1-blockers. In fact neither edible Okinawa Goya rich in CBI nor the propolis Bio 30 has ever caused any side effect during human consumption as foods.

So far no herbal compound has been found to inhibit only PAK4. The majority of herbal anti-melanogenic compounds such as CAPE, curcumin, and shikonin, blocks only PAK1, and a few herbal compounds such as glaucarubinone are known to block both PAK1 and PAK4 (19). In other words, if a given herbal compound inhibits the melanogenesis by only $50 \%$, it is most likely that it is a PAK1-blocker rather than PAK4-blocker, and would be useful for improving our health and extending our lifespan. Of course, we could easily verify its antiPAK1 activity through the quick "Macaroni-Western" kinase assay in the end.

Finally, using this opportunity, we would like to point out the followings: there are so many PAK1- blocking herbal products such as propolis available on the market world-wide which could be very useful for improving our health and even therapy of cancer and many other PAK1-dependent diseases/disorders such as Alzheimer's disease (1). However, unlike FDAapproved drugs, none of them is associated with any reliable international quality control standard such as $\mathrm{IC}_{50}$ or $\mathrm{ED}$ (effective dose). For instance, the quality of propolis depends on the sources of plants where bees harvest from, and the actual content of PAK1-blocking ingredients such CAPE, apigenin, ARC (artepillin C) and propolin $G$ in each propolis. However, since 1960s till present, the only available quality standard used for propolis is either "the total flavonoid content" for CAPE-based propolis or the ARC content in Brazillian green propolis. If these "herbal" healthpromoting products are regulated by a single reliable pharmacological quality standard, we could compare the quality or effectiveness from one sample to another quite objectively.

Hence, we would propose here for the first time to use a universal standard called "Anti-PAK index" which is the $100 \times$ reciprocal of the $\mathrm{IC}_{50}$ in ppm $(\mu \mathrm{g} / \mathrm{mL})$. For instance, "Anti-PAK index" of Bio 30 is 12.5 since its $\mathrm{IC}_{50}$ for $\mathrm{A} 549$ cancer cells is around $8 \mathrm{ppm}$, whereas the "Anti-PAK index" of the "pure" compound CBI is around 1400 , as the $\mathrm{IC}_{50}$ for $\mathrm{A} 549$ is around $140 \mathrm{nM}$ (0.07 ppm). The higher the Anti-PAK index, the more potent a given sample. In other words, $1 \mathrm{mg}$ of CBI is equivalent to $112 \mathrm{mg}$ of Bio 30 for therapy of cancers and many other PAK1-dependent diseases/disorders. This rough estimation is not far from the actual in vivo data where the daily dose of cucurbitacin B $(1 \mathrm{mg} / \mathrm{kg})$, closely related to CBI, and that of Bio $30(50 \mathrm{mg} / \mathrm{kg})$ are their effective dose to suppress the PAK1-dependent growth of pancreatic cancers or NF tumors in mice $(14,20)$, suggesting that their in vivo bioavailability is quite similar.

The only difference between these two is that Bio 30 has been available on the market world-wide for clinical uses for almost a decade, but CBI is not as yet. The only way for us to take CBI is to eat the edible bitter melon (Goya) grown in Okinawa (which contains around $1 \mathrm{~g}$ of CBI per $\mathrm{kg}$ ) or drink Goya tea. Since roughly $90 \%$ of Goya is water, the "Anti-PAK index" of Goya extract/tea could be around 14, pretty close to that of Bio 30. Thus, we shall measure the $\mathrm{IC}_{50}$ of Goya extract/tea on the market for calculating their "AntiPAK index" more precisely.

\section{References}

1. Maruta H. Herbal therapeutics that block the oncogenic kinase PAK1: A practical approach towards PAK1dependent diseases and longevity. Phytother Res. 2014; 28:656-672.

2. Be Tu PT, Nguyen BCQ, Tawata S, Yun, CY, Kim EG, 
Maruta H. PAK1 is essential for the melanogenesis in skin. J Dermatol Sci. 2015; manuscript submitted.

3. Hayashi-Takagi A, Araki Y, Nakamura M, Vollrath B, Duron SG, Yan Z, Kasai H, Huganir RL, Campbell DA, Sawa A. PAKs inhibitors ameliorate schizophreniaassociated dendritic spine deterioration in vitro and in vivo during late adolescence. Proc Natl Acad Sci U S A. 2014; 111:6461-6466.

4. Licciulli S, Maksimoska J, Zhou C, Troutman S, Kota S, Liu Q, Duron S, Campbell D, Chernoff J, Field J, Marmorstein R, Kissil JL. FRAX597, a small molecule inhibitor of the p21-activated kinases, inhibits tumorigenesis of neurofibromatosis type 2 (NF2)associated schwannomas. J Biol Chem. 2013; 288:2910529114.

5. Tagliati F, Bottoni A, Bosetti A, Zatelli MC, degli Uberti EC. Utilization of luminescent technology to develop a kinase assay: Cdk4 as a model system. J Pharm Biomed Anal. 2005; 39:811-814.

6. Oh H, Mun YJ, Im SJ, Lee SY, Song HJ, Lee HS, Woo WH. Cucurbitacins from Trichosanthes kirilowii as the inhibitory components on tyrosinase activity and melanin synthesis of B16/F10 melanoma cells. Planta Med. 2002; 68:832-833.

7. Lee JY, Choi HJ, Chung TW, Kim CH, Jeong HS, Ha KT. Caffeic acid phenethyl ester inhibits alpha-melanocyte stimulating hormone-induced melanin synthesis through suppressing transactivation activity of microphthalmiaassociated transcription factor. J Nat Prod. 2013; 76:13991405.

8. He H, Hirokawa Y, Manser E, Lim L, Levitzki A, Maruta H. Signal therapy for RAS-induced cancers in combination of AG 879 and PP1, specific inhibitors for ErbB2 and Src family kinases, that block PAK activation. Cancer J. 2001; 7:191-202.

9. Rider L, Shatrova A, Feener EP, Webb L, Diakonova M. JAK2 tyrosine kinase phosphorylates PAK1 and regulates PAK1 activity and functions. J Biol Chem. 2007; 282:30985-30996.

10. He H, Hirokawa Y, Gazit A, Yamashita Y, Mano H, Kawakami Y, Kawakami, Hsieh CY, Kung HJ, Lessene G, Baell J, Levitzki A, Maruta H. The Tyr-kinase inhibitor AG879, that blocks the ETK-PAK1 interaction, suppresses the RAS-induced PAK 1 activation and malignant transformation. Cancer Biol Ther. 2004; 3:96-101.

11. Hirokawa Y, Levitzki A, Lessene G, Baell J, Xiao Y, Zhu H, Maruta H. Signal therapy of human pancreatic cancer and NF1-deficient breast cancer xenograft in mice by a combination of PP1 and GL-2003, anti-PAK1 drugs (Tyr-kinase inhibitors). Cancer Lett. 2007; 245:242-251.

12. Deguchi A, Miyoshi H, Kojima Y, Okawa K, Aoki M, Taketo MM. LKB1 suppresses p21-activated kinase-1 (PAK1) by phosphorylation of $\mathrm{Thr}^{109}$ in the $\mathrm{p} 21$-binding domain. J Biol Chem. 2010; 285:18283-18290.

13. Nguyen BCQ, Taira N, Tawata S. Several herbal compounds in Okinawa plants directly inhibit the oncogenic/aging kinase PAK1. Drug Discov Ther. 2014; 8:238-244.

14. Demestre M, Messerli SM, Celli N, Shahhossini M, Kluwe L, Mautner V, Maruta H. CAPE (caffeic acid phenethyl ester)-based propolis extract (Bio 30) suppresses the growth of human neurofibromatosis (NF) tumor xenografts in mice. Phytother Res. 2009; 23:226230.

15. Yun CY, You ST, Kim JH, Chung JH, Han SB, Shin EY, Kim EG. p21-activated kinase 4 critically regulates melanogenesis via activation of the CREB/MITF and $\beta$-catenin/MITF pathways. J Invest Dermatol. 2015; 135:1385-1394.

16. Campos PM, da Silva Horinouchi CD, da Silveira Prudente A, Cechinel-Filho V, de Almeida Cabrini D, Otuki MF. Effect of a Garcinia gardneriana (Planchon and Triana) Zappi hydroalcoholic extract on melanogenesis in B16F10 melanoma cells. J Ethnopharmacol. 2013; 148:199-204.

17. Yoon NY, Eom TK, Kim MM, Kim SK. Inhibitory effect of phlorotannins isolated from Ecklonia cava on mushroom tyrosinase activity and melanin formation in mouse B16F10 melanoma cells. J Agric Food Chem. 2009; 57:4124-4129.

18. Wu J, Wu Y, Yang BB. Anticancer activity of Hemsleya amabilis extract. Life Sci. 2002; 71:2161-2170.

19. Blaskovich MA, Sun J, Cantor A, Turkson J, Jove R, Sebti SM. Discovery of JSI-124 (Cucurbitacin I), a selective janus kinase/signal transducer and activator of transcription 3 signaling pathway inhibitor with potent antitumor activity against human and murine cancer cells in mice. Cancer Res. 2003; 63:1270-1279.

20. Lopez-Haber C, Kazanietz MG. Cucurbitacin I inhibits Rac1 activation in breast cancer cells by a reactive oxygen species-mediated mechanism and independently of janus tyrosine kinase 2 and p-rex1. Mol Pharmacol. 2013; 83:1141-1154.

21. Soda M, Hu D, Endo S, Takemura M, Li J, Wada R, Ifuku S, Zhao HT, El-Kabbani O, Ohta S, Yamamura K, Toyooka N, Hara A, Matsunaga T. Design, synthesis and evaluation of caffeic acid phenethyl ester-based inhibitors targeting a selectivity pocket in the active site of human aldo-keto reductase 1B10. Eur J Med Chem. 2012; 48:321-329.

22. Yeo D, Huynh N, Beutler JA, Christophi C, Shulkes A, Baldwin GS, Nikfarjam M, He H. Glaucarubinone and gemcitabine synergistically reduce pancreatic cancer growth via down-regulation of P21-activated kinases. Cancer Lett. 2014; 346:264-272.

23. Iwanski GB, Lee DH, En-Gal S, Doan NB, Castor B, Vogt M, Toh M, Bokemeyer C, Said JW, Thoennissen NH, Koeffler HP. Cucurbitacin B, a novel in vivo potentiator of gemcitabine with low toxicity in the treatment of pancreatic cancer. Br J Pharmacol. 2010; 160:998-1007.

(Received June 21, 2015; Revised July 23, 2015; Accepted August 24, 2015) 